\title{
Left Atrial Function Assessment in Patients with Rheumatic Mitral Valve Diseases
}

\author{
RANIEN H. EL-SHAFAI, M.Sc.; MAGDY M. EL-MASRY, M.D.; SAHAR A. EL-SHEDOUDY, M.D. and \\ MONA A. EL-SAEDY, M.D.
}

The Department of Cardiology, Faculty of Medicine, Tanta University

\begin{abstract}
Background: The assessment of Left Atrial (LA) function is used in various cardiovascular diseases. LA plays a complementary role in cardiac performance by modulating Left Ventricular (LV) function. Transthoracic two-dimensional (2D) phasic volumes and Doppler echocardiography can measure LA function non-invasively. However, evaluation of LA deformation derived from 2D Speckle Tracking Echocardiography (STE) is a new feasible and promising approach for assessment of LA mechanics. These parameters are able to detect subclinical LA dysfunction in different pathological condition.
\end{abstract}

Aim of Study: To assess left atrial function by conventional echo Doppler study and tissue Doppler based strain imaging as well as global longitudinal strain in patients with rheumatic mitral valve disease.

Patients and Methods: A total of 50 rheumatic mitral valve disease patients appearing consecutively for echocardiogram (ECHO) test at the Cardiology Department in a tertiary care hospital were recruited into the study as per the pre-set inclusion and exclusion criteria. The data were pooled using Microsoft Excel and analysed using SPSS software by application of appropriate statistical tests.

Results: Of the 50 subjects, 22 had Mitral Stenosis (MS), 14 had Mitral Regurgitation (MR), and 14 of them were found to have both MS and MR. The major presenting symptom as observed in 23 patients was dyspnea. LA functions were significantly reduced in double mitral lesion group which was observed in LA indices such as LA emptying fraction, LA passive emptying fraction, atrial fraction, and LA expansion index among groups.

Conclusion: LA reservoir, conduit and contractile function were significantly affected in rheumatic mitral valve disease due to increased hemodynamic load. Global longitudinal strain was significantly reduced in patients with MS and MR.

Key Words: Valvular disease - Left atria - Strain - Contractile function.

Correspondence to: Dr. Ranien H. El-Shafai, The Department of Cardiology, Faculty of Medicine, Tanta University

\section{Introduction}

THE combination of mitral valve disease and atrial inflammation secondary to rheumatic carditis causes Left Atrial (LA) dilatation and fibrosis of atrial wall. These changes lead to elevated left atrial pressure and affection of LA function [1] . LA function has been divided into three phases: First, as a reservoir, the LA stores pulmonary venous return during Left Ventricular (LV) contraction and isovolumetric relaxation. Secondly, as a conduit, the LA transfers blood passively into the LV and thirdly, the LA actively contracts during the final phase of diastole and contributes between 15 and $30 \%$ of LV stroke volume [2]. As a continuum of the LV, especially during diastole, its size and function are very much influenced by the compliance of the LV [3]. Left atrial size and function can be evaluated by multimodality imaging, including echocardiography, cardiac computed tomography, and cardiac magnetic resonance imaging [4], however echocardiography is a simple and widely available tool that has been increasingly used for the non-invasive assessment of LA function [5] Transthoracic two-dimensional (2D) phasic volumes and Doppler echocardiography can measure LA function non-invasively. However, evaluation of LA deformation derived from 2D Speckle Tracking Echocardiography (STE) is a new feasible and promising approach for assessment of LA mechanics. Normal LA function is crucial to maintain normal diastolic and systolic function, and it changes in a variety of disease states, including hypertension, coronary artery disease and mitral valve disease [6]

\section{Patients and Methods}

All patients presented with rheumatic mitral valve diseases who sought follow-up at the outpa- 
tient clinic or who were admitted to Cardiology Department, Tanta University Hospital were screened from June 2017 to June 2018. We screened 160 patients but only fifty patients met the inclusion criteria and were consecutively included in the study.

All study populations was subjected to detailed history taking, full clinical examination, 12 lead electrocardiogram and echocardiography.

The study populations were divided into three groups; group I included 22 patients with rheumatic mitral stenosis at least moderate grade according to mitral valve area [7], group II included 14 patients with rheumatic mitral incompetence at least moderate grade (primary chronic mitral incompetence of rheumatic origin) according to last updates of European valvular heart disease guidelines [7] and group III included 14 patients with combined significant mitral stenosis and incompetence of rheumatic etiology.

\section{Exclusion criteria:}

Patients with LV systolic dysfunction, ejection fraction $<50 \%$, ischemic heart disease, aortic valve diseases more than mild degree, cardiomyopathies, pericardial diseases, prosthetic valve, Atrial Fibrillation (AF) and patients with bad echo window were excluded.

\section{Echocardiography:}

An Echocardiogram was done using vivid-E9 echocardiography (GE) medical systems equipped with M5S probe (frequency 1.7-3.3MHz) for echocardiography. For data acquisition, three complete cardiac cycles were collected and stored in a cine-loop format. Data were acquired with the subjects at rest, lying in the lateral supine position. Data were stored in a digital format and transferred to the Echo Pac for analysis. Echo examination was performed by an experienced operator and reviewed by another experienced operator on using (Echo Pac 110.1.2), from standard apical and parasternal views the following parameters were assessed:

\section{1-2D-Echocharacteristics of $M S$ :}

Including diastolic doming of anterior mitral leaflet, commissural fusion, reduced valve opening, secondary calcification, leaflet tip thickening, sub valvular thickening and Wilkins score: Evaluation of the morphology of the valve is helpful for predicting the hemodynamic results and outcome of percutaneous BMV. A score of 0 to $4+$ is given for leaflet thickness, mobility, calcification, and chordal involvement to provide an overall score that is favorable (low) or unfavorable (high) for valvuloplasty $[\mathbf{8 , 9}]$.

\section{2- Degree of mitral stenosis:}

Valve area using planimetry was the reference measurement of mitral stenosis severity, whereas mean trans-valvular gradient and pulmonary pressures reflect its consequences. The study was conducted to patients with clinically significant (moderate to severe) mitral stenosis i.e. valve area $<1.5 \mathrm{~cm}^{2}[7]$

\section{3- Quantification of mitral incompetence:}

Moderate to severe mitral incompetence according to last updates of valvular heart diseases European guidelines [7].

\section{4- $L A$ volumes and diameters:}

a- The LA diameter was measured from $M$ mode echocardiography in parasternal long axis view.

b- Left atrial volumes: Assessment of LA volumes using area length method, the following volumes were measured from apical 4 chamber views and indexed to Body Surface Area (BSA). The most common method used for the assessment of LA function is based on the measurement of LA phasic volumes: Maximum volume (Volmax) measured just before the opening of the mitral valve, minimal volume (Volmin) measured at the closure of the mitral valve, and the volume just before the atrial contraction, measured at the onset of the $\mathrm{P}$ wave on the ECG (VolP). The following three indices, reflecting the phasic functions of the LA (reservoir, conduit, and booster pump) can be derived from the LA phasic volumes [10]:

$$
\begin{gathered}
\text { LA expansion index }=\frac{(\text { Volmax }- \text { Volmin })}{\text { Volmin }} \text { X100 } \\
\text { LA passive emptying fraction }=\frac{(\text { Volmax }- \text { VolP })}{\text { Volmax }} \text { X100 } \\
\text { LA active emptying fraction }=\frac{(\text { VolP }- \text { Volmin })}{\text { VolP }} \text { X100 } \\
\text { LA ejection fraction (LAEF) }=\frac{(\text { Volmax }- \text { Volmin })}{\text { Volmax }} \text { X100 }
\end{gathered}
$$

\section{5- Left atrial strain and strain rate using TDI and} STE:

Tissue Doppler imaging quantifies regional tissue motion velocity whereas strain and strain rate represent the extent of local tissue deformation and its rate, respectively [11]. Evaluation of LA deformation parameter strain and strain rate were carried out by color TDI using a frame rate of 160- 
$200 \mathrm{MHz}$ and three consecutive beats were recorded from apical 4 and 2 chamber views. LA strain and strain rate were measured offline from color tissue Doppler images of the LA. A narrow sample volume (10 X 2mm) was selected due to the thin atrial walls. The sample volume was placed in two segments (mid septal and lateral walls in the apical four chamber view), three consecutive beats were averaged, the global longitudinal strain was calculated by averaging the twelve segments ((basal, mid and apical segments in each of the four walls: Septal and lateral walls in the apical four chamber view, inferior and anterior walls in the apical two chamber view) and the following parameters were measured from strain and strain rate curves ${ }^{2}$ : Peak Systolic Strain (PSS), and Peak Systolic Strain Rate (PSSR) corresponded to LA reservoir phase. Early diastolic strain rate (ESR) corresponded to LA conduit phase. Late diastolic strain rate (ASR) corresponded to LA booster pump phase.

\section{6- Global longitudinal strain \%:}

Full assessment of the LA function by 2DSTE must include apical 2, 4, and 3 chamber views, optimized for the visualization of the LA. The frame rate should be set between 60 and 80 frames per second [12]. To trace the Region of Interest (ROI) in the discontinuity of the left atrial wall corresponding to pulmonary veins, the direction of LA endocardial and epicardial surfaces at the junction with these structures should be extrapolated [13]. Before processing, a cine loop preview confirms that the internal line follows the LA endocardium throughout the cardiac cycle. Manual adjustments will be made when tracking of the LA endocardium is unsatisfactory. LA segments with inadequate image quality must be rejected. Tracing the LA cavity just before atrial contraction, when it is smaller, often eliminates myocardial wall dropout in the inter-atrial septum and the pulmonary veins and, therefore, improves tracking. Tracking the more hyperdynamic parts of the LA, such as the annular lateral, inferior, and inferior-posterior regions, can be challenging. Extending the LA endocardial trace a little apically below the mitral annulus and adjusting the post-processing settings to better define the LA in this area might be helpful [12].

Duration of the study: This study was done in a period of 1 year starting from June 2017.

\section{Statistical analysis of the data:}

Data were fed to the computer and analyzed using IBM SPSS software package Version 20.0. Qualitative data were described using number and percent. The Kolmogorov-Smirnov test was used to verify the normality of distribution. Quantitative data were described using range (minimum and maximum), mean, standard deviation and median. Significance of the obtained results was judged at the $5 \%$ level.

The used tests were: Chi-square test for categorical variables, to compare between different groups. Monte Carlo correction for chi-square when more than $20 \%$ of the cells have expected count less than 5. F-test (ANOVA) for normally distributed quantitative variables, to compare between more than two groups. Kruskal Wallis test for abnormally distributed quantitative variables, to compare between more than two studied groups, and Post Hoc (Dunn's multiple comparisons test) for pairwise comparisons. Spearman coefficient to correlate between two distributed abnormally quantitative variables.

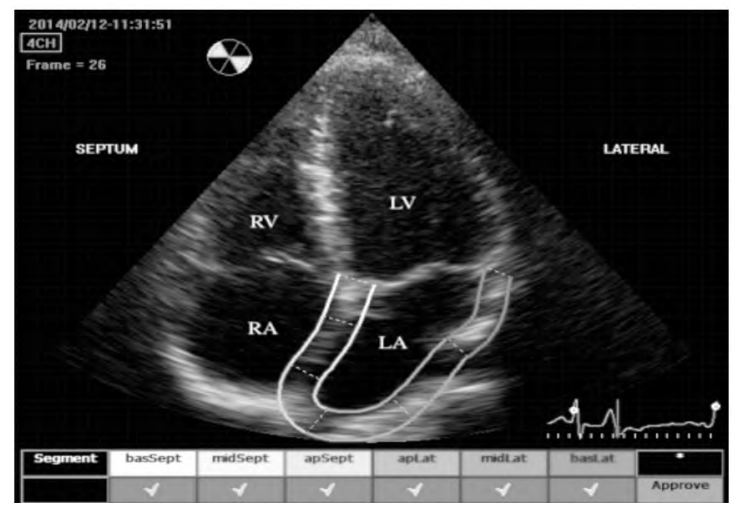

Fig. (1): Four-chamber apical view of speckle tracking strain segments [14]

\section{Results}

Patient demographics: Age: In group I, the age ranged from 35 to 50 years with mean age 43.18 \pm 5.38 years, in group II, it ranged from 22.0 to 50.0 years with mean age $40.71 \pm 7.36$ years and in group III it ranged from 40.0 to 65 years with mean age $51.86 \pm 10.49$ years. There was no statistically significant difference among studied groups regarding age $(p$-value $=0.083)$ (Table 2$)$. Gender: In group I, 15 patients $(68.2 \%)$ were females and 7 patients $(31.8 \%)$ were males. In group II, 12 patients $(85.7 \%)$ were females and 2 patients $(14.3 \%)$ were males. In group III, 8 patients $(57.1 \%)$ were females and 6 patients $(42.9 \%)$ were males. There was no significant difference among studied groups regarding gender $(p$-value $=0.0 .332)($ Table 1$)$.

Regarding the presenting 23 patients $(67.6 \%)$ presented with dyspnea only, one patient presented with palpitation, two patients $(5.9 \%)$ presented 
with fatigue, and now of the patients presented with chest pain (Table 2).

\section{Clinical features of patients:}

- Shortness of breath: In group I, 19 patients (86.4\%) presented with dyspnea. In group II, 10 patients $(71.4 \%)$ presented with dyspnea. In group III, 12 patients $(85.7 \%)$ presented with dyspnea. There was no statistically significant difference among the studied groups $(p$-value $=0.640)$ (Table $3)$.

- Chest Pain: In group I, no patients (0\%) presented with chest pain. In group II no patients $(0 \%)$ presented with chest pain. In group III, 1 patient (7.1\%) presented with chest pain. There was no statistically significant difference among studied groups ( $p$-value 0.553 ) (Table 3 ).

- Easy fatigability: In group I, 5 patients $(22.7 \%)$ presented with fatigue. In group II, 0 patients $(0 \%)$ presented with fatigue. In group III, 5 patients $(35.7 \%)$ presented with fatigue. So patients in group 3 complained of more significant easy fatigability than the other two groups ( $p$-value $=$ 0. 0.042) (Table 3).

- Palpitation: In group I, 0 patients $(0 \%)$ presented with palpitation. In group II, 1 patient $(7.1 \%)$ presented with palpitation. In group III, 2 patients $(14.3 \%)$ presented with palpitation. There was no statistically significant difference among studied groups $(p$-value $=0.098)($ Table 3$)$.

Conventional echocardiography and d tissue Doppler imaging (TDI): Regarding LA diameter, there was no statistically significant difference among the studied groups (Table 4), while LA volumes showed a statistically significant difference as regards LA Vi max, LA Vi min, LA Vi P were higher in group III patients (Table 4).

For LA functions, both LA passive and active emptying fractions were statistically reduced in group III. Also LAEF was significantly reduced in group III compared to other two groups ( $p$-value $<0.001$ ) (Table 5).

Left atrial strain and strain rate GLS and mid septal strain were significantly reduced in group III (Table 6).

Strain rate: All strain rate parameters showed no statistically significant difference among the studied groups (Table 7).

\section{Regarding correlation:}

Significant positive correlation was demonstrated between LA GLS and LAEF ( $r=0.369, p=0.008)$ as shown in Fig. (2). Also, LA GLS had significant positive correlation with mid lateral SSR $(r=0.334$, $p=0.018$ ) as shown in Fig. (3), and lateral annular systolic velocity $(r=0.314, p=0.027)$ as shown in Fig. (4).

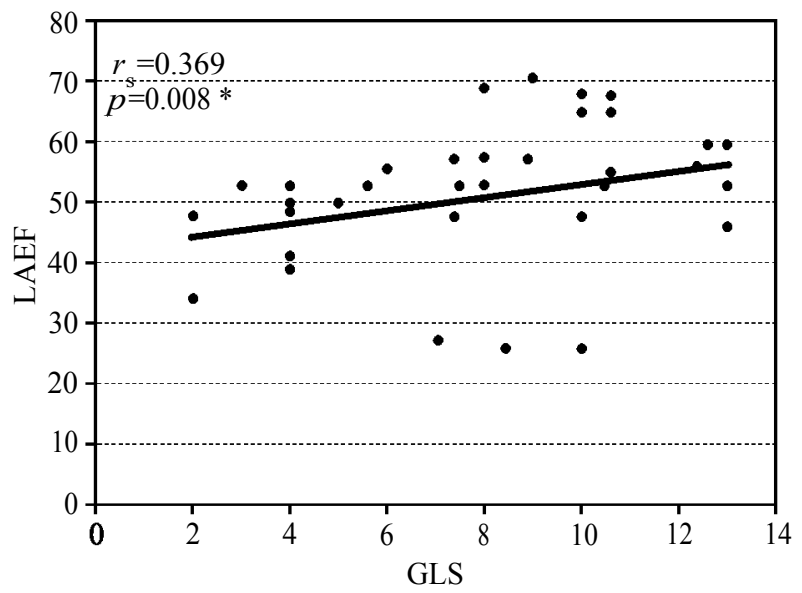

Fig. (2): Correlation between GLS and LAEF in cases group $(n=50)$.

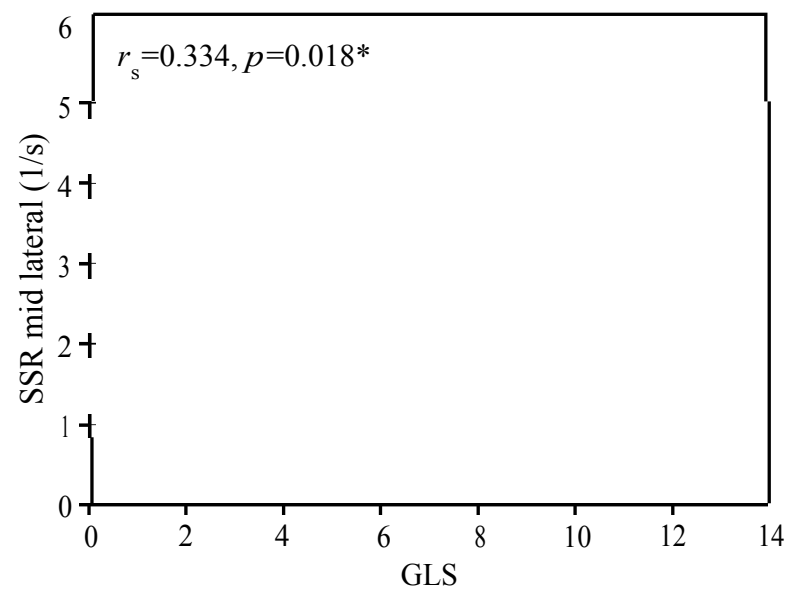

Fig. (3): Correlation between GLS and mid lateral SSR in cases group $(n=50)$.

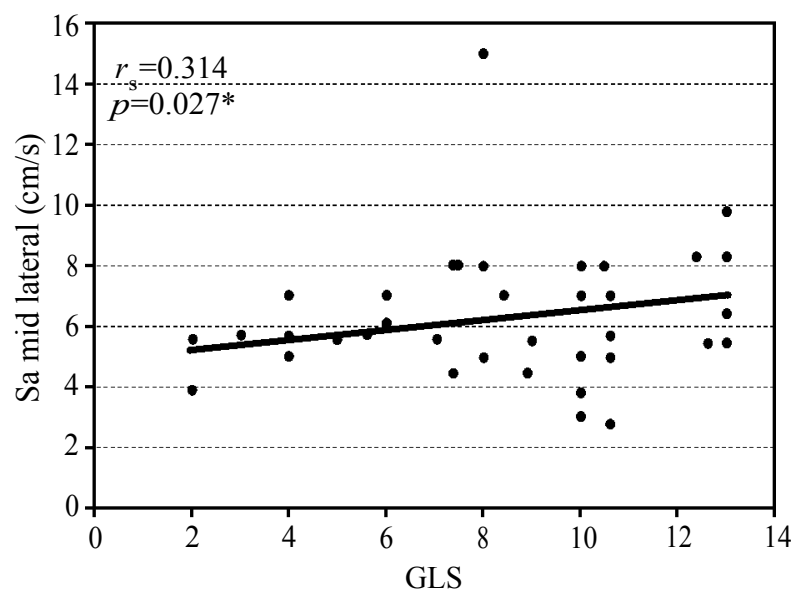

Fig. (4): Correlation between GLS and SA lateral $(\mathrm{cm} / \mathrm{s})$ in cases group $(n=50)$ 
Table (1): Comparison between patients regarding demographic data.

\begin{tabular}{|c|c|c|c|c|c|c|c|}
\hline & \multicolumn{2}{|c|}{$\begin{array}{l}\text { Group I } \\
\text { MS } \\
(\mathrm{n}=22)\end{array}$} & \multicolumn{2}{|c|}{$\begin{array}{l}\text { Group II } \\
\text { Double lesion } \\
(\mathrm{n}=14)\end{array}$} & \multirow[t]{2}{*}{$\begin{array}{l}\text { Test } \\
\text { of sig. }\end{array}$} & \multirow[t]{2}{*}{$p$} & \multirow[t]{2}{*}{ Significance } \\
\hline & No. & $\%$ & No. & $\%$ & & & \\
\hline \multicolumn{8}{|l|}{ Gender: } \\
\hline Male & 7 & 31.8 & 6 & 42.9 & $\chi^{2}=$ & $\mathrm{MC}_{P}=$ & Not \\
\hline Female & 15 & 68.2 & 8 & 57.1 & 3.588 & 0.332 & significant \\
\hline \multicolumn{8}{|l|}{ Age (years): } \\
\hline Min.-max. & \multirow{2}{*}{\multicolumn{2}{|c|}{$\begin{array}{l}35.0-50.0 \\
43.18 \pm 5.38\end{array}$}} & \multirow{2}{*}{\multicolumn{2}{|c|}{$\begin{array}{l}40.0-65.0 \\
51.86 \pm 10.49\end{array}$}} & $\mathrm{H}=$ & 0.083 & \\
\hline Mean \pm SD. & & & & & 6.674 & & significant \\
\hline Median & \multicolumn{2}{|l|}{45.0} & \multicolumn{5}{|l|}{50.0} \\
\hline \multicolumn{8}{|c|}{$\begin{array}{ll}\chi^{2} & : \text { Chi square test. } \\
\text { MC }: \text { Monte Carlo. } & \\
\mathrm{H} \quad: \text { H-value for Kruskal Wallis test, Pairwise comparison bet. each } 2 \text { categories was } \\
\quad \text { done using Post Hoc Test (Dunn's for multiple comparisons test). }\end{array}$} \\
\hline \multicolumn{8}{|c|}{$\begin{array}{l}\text { Table (2): Distribution of patients according to clinical presentation in the } \\
\text { whole study population. }\end{array}$} \\
\hline & & & & \multicolumn{2}{|c|}{ No. } & \multicolumn{2}{|c|}{$\%$} \\
\hline \multicolumn{3}{|c|}{ Dyspnea only } & & \multicolumn{2}{|l|}{23} & \multicolumn{2}{|c|}{67.6} \\
\hline \multicolumn{3}{|c|}{ Palpitation only } & & \multicolumn{2}{|l|}{1} & \multicolumn{2}{|c|}{2.9} \\
\hline \multicolumn{3}{|c|}{ Chest pain only } & & \multicolumn{2}{|l|}{0} & \multicolumn{2}{|c|}{0.0} \\
\hline \multicolumn{3}{|c|}{ Fatigue only } & & \multicolumn{2}{|l|}{2} & \multicolumn{2}{|c|}{5.9} \\
\hline
\end{tabular}

Table (3): Comparison between the study groups regarding clinical presentation.

\begin{tabular}{|c|c|c|c|c|c|c|c|c|c|}
\hline & & \multicolumn{2}{|c|}{$\begin{array}{c}\text { Group I } \\
\text { MS } \\
\mathrm{No}=22\end{array}$} & \multicolumn{2}{|c|}{$\begin{array}{c}\text { Group II } \\
\text { MR } \\
\text { No=14 }\end{array}$} & \multicolumn{2}{|c|}{$\begin{array}{c}\text { Group III } \\
\text { Double lesion } \\
\text { No=14 }\end{array}$} & \multirow[t]{2}{*}{$\begin{array}{c}\text { Test of } \\
\text { significance }\end{array}$} & \multirow[t]{2}{*}{$p$} \\
\hline & & No. & $\%$ & No. & $\%$ & No. & $\%$ & & \\
\hline \multicolumn{10}{|c|}{ Dyspnea: } \\
\hline No & & 3 & 13.6 & 4 & 28.6 & 2 & 14.3 & $\chi^{2}=$ & $\mathrm{MC}_{p}=$ \\
\hline Yes & & 19 & 86.4 & 10 & 71.4 & 12 & 85.7 & 1.459 & 0.640 \\
\hline \multicolumn{10}{|l|}{ NYHA: } \\
\hline 1 & & 15 & 78.9 & 6 & 60.0 & 10 & 83.3 & $\chi^{2}=$ & $\mathrm{MC}_{p}=$ \\
\hline 2 & & 4 & 21.1 & 3 & 30.0 & 2 & 16.7 & 3.540 & 0.499 \\
\hline 3 & & 0 & 0.0 & 1 & 10.0 & 0 & 0.0 & & \\
\hline 4 & & 0 & 0.0 & 0 & 0.0 & 0 & 0.0 & & \\
\hline \multicolumn{10}{|c|}{ Chest pain: } \\
\hline No & & 22 & 100.0 & 14 & 100.0 & 13 & 92.9 & $\chi^{2}=$ & $\mathrm{MC}_{p}=$ \\
\hline Yes & & 0 & 0.0 & 0 & 0.0 & 1 & 7.1 & 2.277 & 0.553 \\
\hline \multicolumn{10}{|c|}{ Fatigue: } \\
\hline No & & 17 & 77.3 & 14 & 100.0 & 9 & 64.3 & $\chi^{2}=$ & $\mathrm{MC}_{p}=$ \\
\hline Yes & & 5 & 22.7 & 0 & 0.0 & 5 & 35.7 & $6.077^{*}$ & $0.042 *$ \\
\hline \multicolumn{10}{|c|}{ Palpitation: } \\
\hline No & & 22 & 100.0 & 13 & 92.9 & 12 & 85.7 & $\chi=$ & $\mathrm{MC}_{p}=$ \\
\hline Yes & & 0 & 0.0 & 1 & 7.1 & 2 & 14.3 & 4.665 & 0.098 \\
\hline $\begin{array}{l}\chi^{2} \\
\mathrm{MC} \\
p \\
* \\
\text { NYHA }\end{array}$ & New & e te & 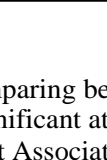 & . & ren & & & & \\
\hline
\end{tabular}


Table (4): Comparison of cases subgroups regarding LA volumes and diameter.

\begin{tabular}{|c|c|c|c|c|c|}
\hline & $\begin{array}{l}\text { Group I } \\
\text { MS } \\
(n=22)\end{array}$ & $\underset{\substack{\text { MR } \\
(n=14)}}{\text { Group II }}$ & $\begin{array}{l}\text { Group III } \\
\text { Double lesion } \\
(\mathrm{N}=14)\end{array}$ & $\begin{array}{l}\text { Test of } \\
\text { sig. }\end{array}$ & $p$ \\
\hline $\begin{array}{l}V \max .\left(\mathrm{ml}^{\prime} / \mathrm{m}^{2}\right): \\
\text { Min.-max. } \\
\text { Mean } \pm \mathrm{SD} . \\
\text { Median } \\
\text { Sig.bet.Grps }\end{array}$ & $\begin{array}{l}66.0-145.0 \\
102.45 \pm 23.17 \\
110.0 \\
\quad p_{1}=0.337\end{array}$ & $\begin{array}{l}50.0-150.0 \\
100.5 \pm 25.43 \\
75.0 \\
p_{2}=0.001 *, p_{3}\end{array}$ & $\begin{aligned} & 57.84-190.0 \\
& 118.41 \pm 37.91 \\
122.0 & \\
= & 0.044^{*}\end{aligned}$ & $\begin{array}{l}\mathrm{H}= \\
15.465^{*}\end{array}$ & $<0.001 *$ \\
\hline $\begin{array}{l}V \min .\left(\mathrm{ml}^{2} \mathrm{~m}^{2}\right): \\
\text { Min.-max. } \\
\text { Mean } \pm \text { SD. } \\
\text { Median } \\
\text { Sig.bet.Grps }\end{array}$ & $\begin{array}{l}34.0-108.0 \\
66.0 \pm 15.92 \\
66.0 \\
\quad p_{1}=0.068\end{array}$ & $\begin{array}{l}39.0-80.0 \\
52.79 \pm 12.87 \\
53.50 \\
p_{2}=0.002 *, p_{3}\end{array}$ & $\begin{aligned} & 42.50-110.0 \\
& 74.57 \pm 17.96 \\
& 90.75 \\
< & 0.001 *\end{aligned}$ & $\begin{array}{l}\mathrm{H}= \\
16.232 *\end{array}$ & $<0.001 *$ \\
\hline $\begin{array}{l}V P\left(\mathrm{ml}^{2} \mathrm{~m}^{2}\right): \\
\text { Min.-max. } \\
\text { Mean } \pm \text { SD. } \\
\text { Median } \\
\text { Sig.bet.Grps }\end{array}$ & $\begin{array}{l}14.0-55.0 \\
35.45 \pm 11.63 \\
36.0 \\
\quad p_{1}=0.024\end{array}$ & $\begin{array}{l}25.0-74.0 \\
49.79 \pm 14.77 \\
50.50 \\
p_{2}<0.001 *, p\end{array}$ & $\begin{array}{l}53.0-114.0 \\
76.86 \pm 19.36 \\
71.50 \\
3=0.005^{*}\end{array}$ & $\begin{array}{l}\mathrm{H}= \\
28.663^{*}\end{array}$ & $<0.001 *$ \\
\hline $\begin{array}{l}\text { LA anterior -poster } \\
\text { diameter by } M M(\mathrm{~cm}) \text { : } \\
\text { Min.-max. } \\
\text { Mean } \pm \text { SD. } \\
\text { Median }\end{array}$ & $\begin{array}{l}4.50-6.0 \\
5.16 \pm 0.61 \\
5.0\end{array}$ & $\begin{array}{l}4.50-7.0 \\
5.45 \pm 0.70 \\
5.23\end{array}$ & $\begin{array}{l}4.50-6.70 \\
5.16 \pm 0.71 \\
5.0\end{array}$ & $\begin{array}{l}\mathrm{F}= \\
0.921\end{array}$ & 0.405 \\
\hline $\begin{array}{l:}\mathrm{F}: \mathrm{F} \text {-value for ANOVA t } \\
\mathrm{H}: \text { H-value for Kruskal } \mathrm{W} \\
\text { (Dunn's for multiple c } \\
p: p \text {-value for comparing } \\
p_{1}: p \text {-value for comparing } \\
p_{2}: p \text {-value for comparing } \\
p_{3}: p \text {-value for comparing } \\
*^{3}: \text { Statistically significan }\end{array}$ & $\begin{array}{l}\text { Pairwise compa } \\
\text { lis test, Pairwise } \\
\text { parisons test). } \\
\text { tween different } \\
\text { tween MS and } \mathrm{I} \\
\text { tween MS and D } \\
\text { tween MR and I } \\
p \leq 0.05 \text { LA }=\mathrm{L}\end{array}$ & $\begin{array}{l}\text { ison bet. each } 2 \mathrm{~g} \\
\text { omparison bet. ec } \\
\text { coups. } \\
\text { R. } \\
\text { buble lesion. } \\
\text { ouble lesion. } \\
\text { t Atrium. }\end{array}$ & $\begin{array}{l}\text { groups was done usi } \\
\text { ach } 2 \text { categories wa: } \\
\\
\text { Vmax : Maximum } 1 \\
\text { Vmin : Minimum le } \\
\text { Vp : Pre atrial co } \\
\text { MM } \\
\text { LA : M-Mode. } \\
\text { : Left Atrium }\end{array}$ & $\begin{array}{l}\text { atrial volum } \\
\text { atrial volum } \\
\text { raction left a }\end{array}$ & $\begin{array}{l}\text { ukey). } \\
\text { oc Test } \\
\text { volume. }\end{array}$ \\
\hline
\end{tabular}

Table (5): LA fractions the study population.

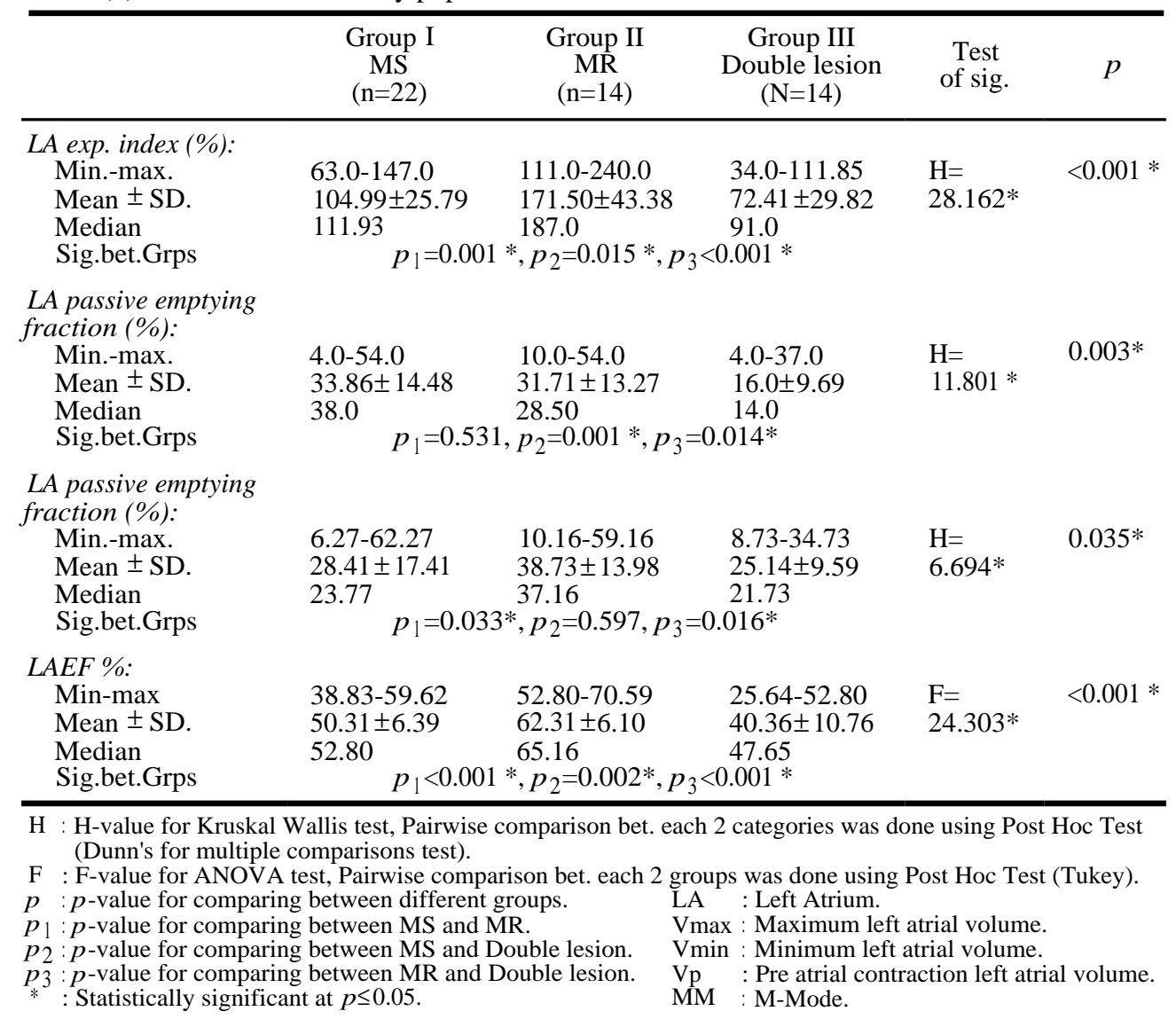


Table (6): Comparison between patients sub groups regarding the global left atrial strain and strain measurements.

\begin{tabular}{|c|c|c|c|c|c|}
\hline & $\begin{array}{l}\text { Group I } \\
\text { MS } \\
\text { No=22 }\end{array}$ & $\begin{array}{c}\text { Group II } \\
\text { MR } \\
\mathrm{No}=14\end{array}$ & $\begin{array}{c}\text { Group III } \\
\text { Double lesion } \\
\text { No=14 }\end{array}$ & $\mathrm{H}$ & $p$ \\
\hline \multicolumn{6}{|l|}{ GLS: } \\
\hline Min.-max. & $4-13.0$ & $4-10.60$ & $2-10.0$ & \multirow[t]{3}{*}{$6.568^{*}$} & \multirow[t]{3}{*}{$0.037 *$} \\
\hline Mean \pm SD & $9.04 \pm 2.40$ & $8.55 \pm 1.01$ & $6.18 \pm 2.95$ & & \\
\hline Median & 9.24 & 8.95 & 7.04 & & \\
\hline \multicolumn{6}{|c|}{$\varepsilon$ mid septal $(\%):$} \\
\hline Min.-max. & $6.0-50.20$ & $6.0-39.0$ & $6.0-17.92$ & \multirow{4}{*}{$8.039 *$} & \multirow{4}{*}{$0.018^{*}$} \\
\hline Mean \pm SD & $18.38 \pm 12.02$ & $25.57 \pm 11.32$ & $12.11 \pm 4.33$ & & \\
\hline Median & 15.0 & 29.0 & 12.79 & & \\
\hline Sig.bet.Grps & \multicolumn{3}{|c|}{$p_{1}=0.060, p_{2}=0.220, p_{3}=0.005^{*}$} & & \\
\hline \multicolumn{6}{|c|}{$\varepsilon$ mid lateral $(\%):$} \\
\hline Min.-max. & $2.42-56.80$ & $10.0-38.0$ & $2.40-28.0$ & $16.275^{*}$ & $<0.001 *$ \\
\hline Mean \pm SD. & $11.55 \pm 12.39$ & $27.39 \pm 8.83$ & $16.26 \pm 11.67$ & & \\
\hline Median & 7.23 & 30.0 & 18.0 & & \\
\hline Sig.bet.Grps & \multicolumn{4}{|c|}{$p_{1}<0.001^{*}, p_{2}=0.365, p_{3}=0.006^{*}$} & \\
\hline
\end{tabular}

$\mathrm{H}: \mathrm{H}$-value for Kruskal Wallis test, Pairwise comparison bet. each 2 categories was done using Post Hoc Test (Dunn's for multiple comparisons test).

$p: p$-value for comparing between different groups.

$p_{1}: p$-value for comparing between MS and MR. $\quad * \quad:$ Statistically significant at $p \leq 0.05$.

$p_{2}: p$-value for comparing between MS and Double lesion. GLS : Global Longitudinal Strain.

$p_{3}: p$-value for comparing between MR and Double lesion. $\varepsilon:$ Strain.

Table (7): Comparison between patients sub groups regarding strain rate measurements.

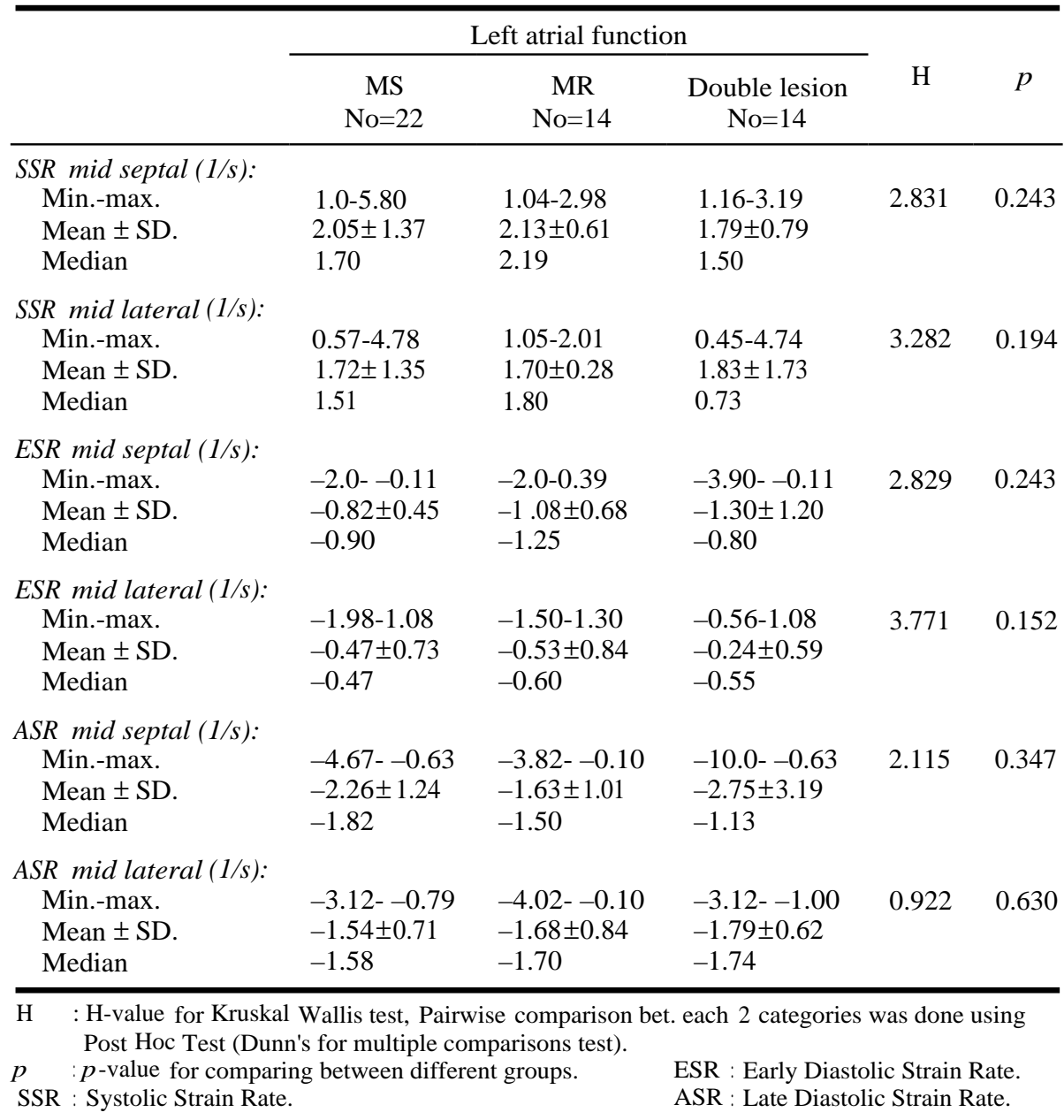




\section{Discussion}

Left Atrium (LA), in a close interdependence with LV, plays a key role in maintaining an optimal cardiac performance. The atrium contributes up to $30 \%$ of total LV stroke volume in normal individuals (with an increased contribution with LV dysfunction). The loss of atrial contribution of LV filling and stroke volume with AF patients often leads to symptomatic deterioration. A thorough assessment of LA size, function and structure may have important clinical, prognostic and therapeutic implications.

Recent advances in cardiac imaging allow accurate assessment of LA remodeling. Echocardiography remains the investigation of clinical choice for measuring LA volumes [15].

Abnormal LA function had been associated with poor prognosis and symptom development in asymptomatic patients [16].

In a recent study of patients with asymptomatic rheumatic mitral stenosis (mean mitral valve area $1.5 \pm 0.4 \mathrm{~cm}^{2}$ ) followed for 3 years, LAV was not significantly increased, and TDI mean SR-S significantly decreased in patients with clinical events (symptoms, hospitalization, AF, thromboembolic events, valve surgery, or percutaneous valvuloplasty) compared with those without events; the LA ejection fraction and the LA expansion index were similar in both groups (symptomatic and asymptomatic). The best independent predictor of events in this study was SR-S; a cutoff value of $-1.69 \mathrm{~s}$ was predictive of events with sensitivity and specificity of $88 \%$ and $80.6 \%$, respectively [17]. These investigators later showed that LA peak strain was the best predictor of AF over 4 years in 101 asymptomatic patients with isolated rheumatic mitral stenosis [18]. These data suggest that the degree of underlying atrial remodeling with associated impaired reservoir capacity (i.e., atrial stiffness) can predict the development of symptoms and cardiovascular events independent of mitral valve area. Also dilated LA per se (M-mode diameter $>50 \mathrm{~mm}$ or LA volume $>60 \mathrm{~mL} / \mathrm{m}^{2}$ ) had been suggested as an indicator or oral anticoagulants use in patients with MS and sinus rhythm as recommended by the European society of cardiology, (recommendation class IIa, level of evidence C) [7].

Reversed LA remodeling after successful percutaneous balloon valvotomy in symptomatic MS patients has a prognostic clinical impact on cerebrovascular events as well [19]. LA prognostic ability wasn't found only in patients with MS but also in patients with MR as it had been proved that LA diameter $\geq 55 \mathrm{~mm}$ was associated with lower 8year survival and independently predicted overall mortality and cardiac mortality in both symptomatic and asymptomatic patients with primary MR under medical treatment, respectively [20]. Also, increased $\mathrm{LAVi} \geq 60 \mathrm{ml} / \mathrm{m}^{2}$ in MR patients treated medically had increased mortality and more cardiac events ( $\mathrm{AF}$ and heart failure) than those with LAVi $<40$ $\mathrm{ml} / \mathrm{m}^{2}$ [21]. So the magnitude of LA dilation has been shown to be a determinant of outcome in patients with severe primary MR that is additive to the standard indications for surgery. As a result, severe left atrial dilation on echocardiography ( $>60$ $\mathrm{ml} / \mathrm{m}^{2}$ ) appeared as a class IIa recommendation for consideration for surgical mitral valve repair in 2017 ESC/EACTS Guidelines for the management of valvular heart disease [7].

So being of great importance in determining the prognosis and the decision for intervention in patients with mitral valve disease the current study was carried out to assess left atrial function in patients with mitral valve disease using conventional methods and compare them to new methods that determine longitudinal myocardial velocities as strain and strain rate.

\section{Regarding $L A$ volumes and fractions:}

LA volumes were significantly higher in patients with combined mitral stenosis and regurgitation, this could be explained by pressure and volume overload mediated LA remodeling [22] and so LA fractions were significantly reduced in group III in comparison with I and II [23]. This also came in agreement with the study conducted by Borg et al. [24], in which LA volumes were higher in MR in all phases. In controversy with our study, the study conducted by Shetty et al., aimed to assess Left Atrial (LA) function by observing the differences in conventional Doppler echo parameters of left ventricular inflow and LA appendage among patients with mitral valve disease. This study showed no significant difference in LA indices such as LA active emptying fraction, LA passive emptying fraction and LA expansion index among groups having MR and no MR.

\section{Strain and strain rate:}

LA reservoir function was significantly reduced in patients with mixed significant mitral stenosis and regurgitation as presented with GLS and mid septal strain.

LA reservoir function was significantly reduced in mitral stenosis patients as presented with mid lateral strain. 
As regard to $\mathrm{SSr}, \mathrm{ESr}$ and Asr there was no significant difference among the patient sub-groups.

Regarding Doppler-based LA strain and strain rate imaging, it is a quantitative technique that estimates myocardial contractility relatively independent of changes in cardiac rotational motion and tethering effects [25]. LA systolic strain and peak systolic strain rate are closely related to the LA reservoir function [26]. The LA reservoir function is assessed in two consecutive phases as early and late. While the early reservoir function depends on LA relaxation, the late reservoir function depends on LV contraction through the descent of the base during systole. Therefore, both LA relaxation and LV systolic function might affect the LA reservoir function and so LA peak systolic strain [27]. LA intrinsic myocardial properties (relaxation and compliance) are affected in mitral valve disease patients [28].

Mid septal strain was significantly reduced in group III most probably due to a membranous thin septal wall as compared with other LA walls, and sensitivity to the left atrial pressure and volume changes [25].

In mitral regurgitation, the volume overload of the left atrium is proportional to the severity of regurgitation, but there is much less systolic dysfunction than with mitral stenosis; many patients even exhibit an increase in the reservoir SR, possibly due to a rise in atrial compliance. They also exhibit an increase in the passive conduit atrial $\mathrm{SR}$, which is attributable to the rise in gradient during early diastole, and also shown by the increase in the peak E velocity of the trans-mitral flow. The left atrial pump function decreases due to the rise in left ventricular diastolic pressure, that is, the rise in atrial afterload. The increase in the reservoir and conduit atrial SR in mitral regurgitation might explain the different time sequence in the development of AF seen in mitral stenosis and mitral regurgitation. These explain why lateral wall strain was significantly reduced in group I. Also increased LA compliance can explain why GLS is higher in group II [25] .

Due to inflow obstruction, the atrial booster pump contributes less to LV filling in mitral stenosis even during sinus rhythm, despite a proportional increase, with increasing severity, in the LA preload. The impaired atrial reservoir and pump function are associated with a reduction in LA compliance and intrinsic myocardial contractility [11].

Peak systolic SR is a more sensible index of atrial dysfunction than atrial diameter and volume, because in atrial diseases, it is changed before a clear increase in atrial dimensions and volumes [17].

The changes in peak systolic atrial myocardial deformation properties in patients with MS may be due to disorganization of the atrial muscle bundles, extent of fibrosis and expansion of extracellular matrix in addition to an increase in cell size, myolysis, and perinuclear accumulation of glycogen [26]

In the presence of the same degree of MS as assessed by the standard echocardiographic study, patients may become symptomatic and show a different prognosis, because of different degrees of atrial muscle bundles disorganization and atrial fibrosis, causing atrial stiffness and atrial reservoir dysfunction. These atrial alterations may be demonstrated by SRI [26]

Impaired myocardial deformation in late diastole could be explained by impaired intrinsic LA myocardial properties, increased LA afterload and high LA preload in cases of pulmonary hypertension. All these factors results in LA dilatation that exceeds the optimal Frank-Starling law relationship [16].

In controversy, Shetty et al., [22] in their study conducted on 43 mitral valve disease patients (39 had MS, 3 had MR, 2 had double lesion) aimed to assess LA function demonstrated that there was no significant change in LA GLS among groups with MR and without MR. This could be explained by few numbers of mitral regurgitation and double lesion patients in their study.

This also came in agreement with the study conducted by Her et al. [27], who demonstrated that left atrial global strain was significantly correlated with the degree of LA fibrosis ( $r=-0.55$, $p<0.001$ ).

Impairment of LA strain in MR came in agreement with the study conducted by Debonnaire et al., [28]

MR patients with a history of recurrent AF showed lower strain values when compared with patients affected by the same degree of MR without $\mathrm{AF}$ recurrence, as mentioned in the study conducted by Cameli et al., [19].

On the contrary the study conducted by Borg et al., [24] , carried out on 27 chronic primary moderately severe degenerative mitral incompetence also demonstrated that reservoir phase strain $(32.91 \pm 14.26 \%), \operatorname{SSr}(2.65 \pm 0.87), \mathrm{ESr}(-2.02 \pm$ 
$0.58)$, and $\left.\operatorname{ASr}\left(2.55 \pm 1.31 \mathrm{~s}^{-1}\right)\right)$ were increased $(23.14 \pm 7.96 \%, 1.62 \pm 0.53,1.29 \pm 0.59,1.98 \pm 0.65$ $\mathrm{s}\left({ }^{-1}\right)$, in controls, respectively, $p<$ or $\left.=0.004\right)$. Also enhanced conduit function as evidenced by increased peak trans-mitral E wave. Despite enhanced SR-A in MR, LA EF was unchanged (31.34 vs. $29.23 \%, p=\mathrm{ns}$ ), and LA contractile tissue velocity (A') was reduced $(-5.39 \pm 1.95$ vs. $-6.91 \pm 1.80 \mathrm{~cm} / \mathrm{s}$, $p=0.006)$. Increase in SSR-and reservoir strain possibly due to enhanced atrial compliance. Passive LV filling is increased in MR. This has been attributed to an increased atrio-ventricular gradient, decreased LV chamber stiffness and increased recoil of the LA. In MR, this enhancement of conduit function may diminish with declining LV function which is also accompanied by a decrease in $\mathrm{E}$ wave deceleration time, consistent with the onset of increased LV stiffness. Since MR is a state of enhanced preload, patients had increased contractile volumes and ASR.

This came in agreement with the study conducted by Caso et al., [18] . They suggested that LA strain rate emerged as the best predictor of events in patients with mitral stenosis, in a multivariate analysis that also included age, LA volume, and mitral valve area. A cut-off value of 1.69/s for LA peak Systolic Strain rate (SSr) predicted events with a sensitivity of $88 \%$ and a specificity of $80.6 \%$. Also they reported in their study that prognosis is worse in the presence of lower peak systolic SR values in patients with the same degree of MS, because of different degree of atrial myopathy, fibrosis, and stiffness.

\section{Limitations of the study with future direction:}

1- The sample size was small as large number of patients were excluded because of AF also, the present study is not a population based study and hence subject to several biases inherent in such studies. For example, symptomatic lesions are more likely to be represented in a study based in a tertiary referral center.

2- We have not assessed pulmonary venous inflow, which could potentially provide more information on LA function, due to difficulty in obtaining good pulmonary vein traces in our population using transthoracic echocardiography.

3- Like other Doppler modalities, DTI-derived strain measurements are angle dependent, and the need to manually track the LA wall and reposition the region of interest on each wall frame by frame makes using this method in a clinical setting prohibitively time-consuming.

4- Some considerations should be taken into account when analyzing the myocardial function of the LA by strain and strain rate as it is still Vendor-dependent.

\section{Conclusion:}

LA myocardial analyses (strain and strain rate analysis) are feasible in patients with rheumatic mitral valve disease. LA reservoir, conduit and contractile function were significantly affected in rheumatic mitral valve disease due to increased hemodynamic load. Global longitudinal strain was significantly reduced in patients with MS and MR.

\section{References}

1- ESSOP M.R. and NKOMO V.T.: Rheumatic and nonrheumatic valvular heart disease: Epidemiology, management, and prevention in Africa. Circulation, 112 (23): 3584-91, 2005.

2- MAGDY G., EL-ASHMAWY H., ZIDAN A. and SAEED A.: Left atrial myocardial deformation characteristics in patients presenting with ST elevation myocardial infarction. The Egyptian Heart Journal. [accessed 2018 May 18], 68 (3): 181-6, 2016.

3- KURT M., WANG J., TORRE-AMIONE G. and NAGUEH S.F.: Left atrial function in diastolic heart failure. Circulation: Cardiovascular Imaging, 2 (1): 10-5, 2009.

4- ANDERSON J.L., HORNE B.D. and PENNELL D.J.: Atrial dimensions in health and left ventricular disease using cardiovascular magnetic resonance. Journal of Cardiovascular Magnetic Resonance, 7 (4): 671-5, 2005.

5- TOPS L.F., VAN DER WALL E.E., SCHALIJ M.J. and BAX J.J.: Multi-modality imaging to assess left atria size, anatomy and function. Heart, 93 (11): 1461-70, 2007.

6- OXBOROUGH D., WHYTE G., WILSON M., O'HANLON R., BIRCH K., SHAVE R., SMITH G., GODFREY R., PRASAD S. and GEORGE K.: A depression in left ventricular diastolic filling following prolonged strenuous exercise is associated with changes in left atrial mechanics. Journal of the American Society of Echocardiography, 23 (9): 968-76, 2010.

7- BAUMGARTNER H., FALK V., BAX J.J., De BONIS M., HAMM C., HOLM P.J., IUNG B., LANCELLOTTI P., LANSAC E., RODRIGUEZ MUÑOZ D., et al.: ESC/ EACTS Guidelines for the management of valvular heart disease. European Heart Journal, 38 (36): 2739-91, 2017.

8- BAUMGARTNER H., HUNG J., BERMEJO J., CHAMBERS J.B., EVANGELISTA A., GRIFFIN B.P., IUNG B., OTTO C.M., PELLIKKA P.A. and QUIÑONES M.: Echocardiographic assessment of valve stenosis: EAE/ASE recommendations for clinical practice. European Journal of Echocardiography, 10 (1): 1-25, 2009.

9- NUNES M.C.P., TAN T.C., ELMARIAH S., DO LAGO R., MARGEY R., CRUZ-GONZALEZ I., ZHENG H., HANDSCHUMACHER M.D., INGLESSIS I., PALACIOS I.F., et al.: The echo score revisited: Impact of incorporating commissural morphology and leaflet displacement to the prediction of outcome for patients undergoing percutaneous mitral valvuloplasty. Circulation, 129 (8): 886-95, 2014

10- JIAMSRIPONG P., HONDA T., REUSS C.S., HURST R.T., CHALIKI H.P., GRILL D.E., SCHNECK S.L., 
TYLER R., KHANDHERIA B.K. and LESTER S.J.: Three methods for evaluation of left atrial volume. European Journal of Echocardiography, 9 (3): 351-5, 2008.

11- ZHANG Q., YIP GW.K. and YU C.M.: Approaching regional left atrial function by tissue Doppler velocity and strain imaging. Europace, 10 (Supplement 3): iii62iii69, 2008 .

12- GYU K.D., JIN L.K., SAHNG L., SO-YEON J., SOOK L.Y., JEONG C.Y., SOO Y.H., HEE K.J., TAE J.K., CHANG P.S., et al.: Feasibility of Two-Dimensional Global Longitudinal Strain and Strain Rate Imaging for the Assessment of Left Atrial Function: A Study in Subjects with a Low Probability of Cardiovascular Disease and Normal Exercise Capacity. Echocardiography, 26 (10): 1179-87, 2009.

13- CAMELI M., CAPUTO M., MONDILLO S., BALLO P., PALMERINI E., LISI M., MARINO E. and GALDERISI M.: Feasibility and reference values of left atrial longitudinal strain imaging by two-dimensional speckle tracking. Cardiovascular Ultrasound, 7 (1). Doi: 10.1186/14767120-7-6, 2009

14- VIZZARDI E., D'ALOIA A., ROCCO E., LUPI L. ROVETTA R., QUINZANI F., BONTEMPI L., CURNIS A. and DEI CAS L.: How should we measure left atrium size and function? Journal of Clinical Ultrasound, 40 (3): 155-66, 2012.

15- ABHAYARATNA W.P., SEWARD J.B., APPLETON C.P., DOUGLAS P.S., OH J.K., TAJIK A.J. and TSANG T.S.M.: Left Atrial Size. Physiologic Determinants and Clinical Applications. Journal of the American College of Cardiology, 47 (12): 2357-63, 2006.

16- ROSCA M., LANCELLOTTI P., POPESCU B.A. and PIÉRARD L.A.: Left atrial function: Pathophysiology, echocardiographic assessment, and clinical applications. Heart, 97 (23): 1982 LP-1989, 2011.

17- CASO P., ANCONA R., Di SALVO G., COMENALE PINTO S., MACRINO M., Di PALMA V., D'ANDREA A., MARTINIELLO A.R., SEVERINO S. and CALABRÒ R.: Atrial reservoir function by strain rate imaging in asymptomatic mitral stenosis: Prognostic value at 3 year follow-up. European Journal of Echocardiography, 10 (6): 753-9, 2009

18- ANCONA R., COMENALE PINTO S., CASO P., Di SALVO G., SEVERINO S., D'ANDREA A. and CALABRÒ R.: Two-Dimensional Atrial Systolic Strain Imaging Predicts Atrial Fibrillation at 4-Year Follow-Up in Asymptomatic Rheumatic Mitral Stenosis. Journal of the American Society of Echocardiography. 2013 [accessed Jul. 17], 26 (3): 270-7, 2018.

19-VIEIRA M.L.C., SILVA M.C., WAGNER C.R., DALLAN L.A., KAJITA L.J., OLIVEIRA W.A., SAMESINA N., HOTTA V.T., MATHIAS Jr. W., SPINA G., et al.: Left Atrium Reverse Remodeling in Patients With Mitral Valve
Stenosis After Percutaneous Valvuloplasty: A 2-and 3Dimensional Echocardiographic Study. Revista Española de Cardiología (English Edition), 66 (1): 17-23, 2013.

20- HOIT B.D.: Left Atrial Size and Function: Role in Prognosis. Journal of the American College of Cardiology. 2014 [accessed Jul. 17], 63 (6): 493-505, 2018.

21- RUSINARU D., TRIBOUILLOY C., GRIGIONI F., AVIERINOS J.F., SURI R.M., BARBIERI A., SZYMANSKI C., FERLITO M., MICHELENA H., TAFANELLI L., et al.: Left atrial size is a potent predictor of mortality in mitral regurgitation due to flail leaflets results from a large international multicenter study. Circulation: Cardiovascular Imaging, 4 (5): 473-81, 2011.

22- SHETTY R.K., NAYAK K., RAO K.N., SAMANTH J., BALAJI O., BHATTACHARJEE D. and KOTIAN R.P.: Assessment Of Left Atrial Function In Patients With Mitral Valve Diseases. Asian Journal of Pharmaceutical and Clinical Research, 9 (6): 335-9, 2016.

23- TODARO M.C., CHOUDHURI I., BELOHLAVEK M., JAHANGIR A., CARERJ S., ORETO L. and KHANDHERIA B.K.: New echocardiographic techniques for evaluation of left atrial mechanics. European Heart Journal Cardiovascular Imaging, 13 (12): 973-84, 2012.

24- BORG A.N., PEARCE K.A., WILLIAMS S.G. and RAY S.G.: LEFT atrial function and deformation in chronic primary mitral regurgitation. European journal of echocardiography: The Journal of the Working Group on Echocardiography of the European Society of Cardiology, 10 (7): 833-40, 2009

25- SHIN M.S., KIM B.R., OH K.J., BONG J.M., CHUNG W.J., KANG W.C., HAN S.H., MOON C.IL., AHN T.H., CHOI I.S., et al.: Echocardiographic Assessments of Left Atrial Strain and Volume in Healthy Patients and Patients With Mitral Valvular Heart Disease by Tissue Doppler Imaging and 3-Dimensional Echocardiography. Korean Circulation Journal, 39 (7): 280-7, 2009.

26- THIEDEMANN K.U. and FERRANS V.J.: Left atrial ultrastructure in mitral valvular disease. The American Journal of Pathology, 89 (3): 575-604, 1977.

27- HER A.Y., CHOI E.Y., SHIM C.Y., SONG B.W., LEE S., HA J.W., RIM S.J., HWANG K.C., CHANG B.C. and CHUNG N.: Prediction of Left Atrial Fibrosis With Speckle Tracking Echocardiography in Mitral Valve Disease: A Comparative Study With Histopathology. Korean Circulation Journal, 42 (5): 311-8, 2012.

28- DEBONNAIRE P.J., LEONG D.P., WITKOWSKI T.G., AL-AMRI I., JOYCE E.M., KATSANOS S., SCHALIJ M.J., BAX J.J., DELGADO V. and AJMONE MARSAN N.: Abstract 11513: Assessment of Left Atrial Function By 2D-Speckle Tracking Echocardiography in Patients With Severe Organic Mitral Regurgitation: Association With Surgical Indication. Circulation, 126 (Suppl 21): A11513 LP-A11513, 2012. 


\section{تقييم وظيفة الآذين الآيسر في المرضى الذين يعانون من إعتلال بألصمام المترالى الناتج عن الحمى الروماتزمينة}

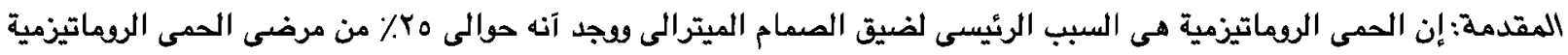

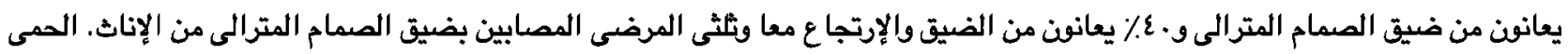

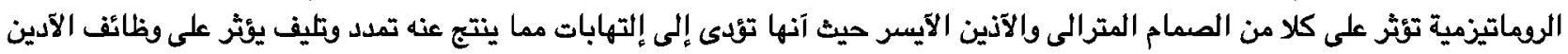

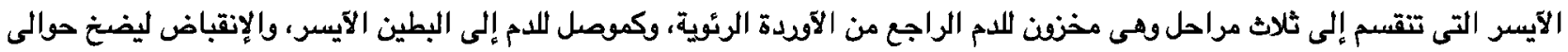
• بَّ من الدم آثناء إنبساط البطين الآيسر.

إن حجم ووظيفة الآذين الآيسر يمكن تقيمهما بوسائل متعددة تتضمن الآشعة المقطعية والرنين المغناطيسى على عضلة القلب ولكن تظل الموجات الفوق صوتية هى حجر الآساس.

الهدف من الدراسة: تقييم وظيفة الآذين الآيسر فى المرضى الذين يعانون من إعتلال بالصمام المترالى الناتج عن الصمى الروماتيزمية بواسطة دوبلر الآنسجة.

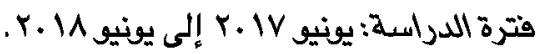

$$
\begin{aligned}
& \text { ولجميع الحالات تم عمل الآتى: } \\
& \text { ا - آخذ التاريخ المرضى اللحالة. } \\
& \text { r- r عمل رسم قلب كامل. } \\
& \text { r- عما آشعة عادية على الصدر. } \\
& \text { ع- عمل موجات فق صوتية على القلب. }
\end{aligned}
$$

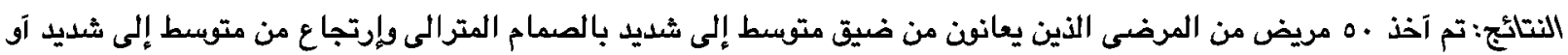

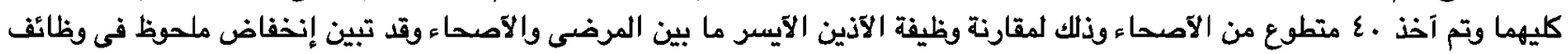

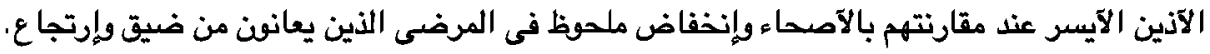

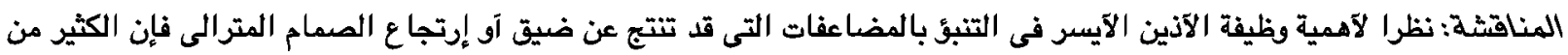

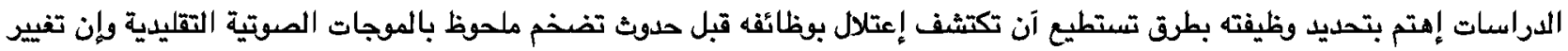

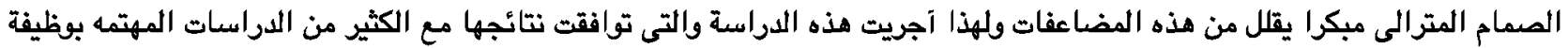

